\title{
O GARANTISMO E OS \\ PRECEDENTES DA CORTE INTERAMERICANA DE \\ DIREITOS HUMANOS: EFEITO VINCULANTE AOS ESTADOS SOB SUA JURISDIÇÃO
}

GUARANTEEISM AND THE PRECEDENTS OF THE INTER-AMERICAN COURT OF HUMAN RIGHTS: BINDING EFFECT ON THE COUNTRIES UNDER ITS JURISDICTION

EL GARANTISMO Y LOS PRECEDENTES DE LA CORTE INTERAMERICANA DE DERECHOS HUMANOS: EFECTO VINCULANTE A LOS ESTADOS BAJO SU JURISDICCIÓN

Nestor Eduardo Araruna Santiago ${ }^{1}$

Eduardo Almendra Martins²

1 Doutor em Direito Tributário (2005); Mestre (2000) e Especialista (2000) em Ciências Penais pela Universidade Federal de Minas Gerais. Professor Titular do Programa de PósGraduação em Direito Constitucional da Universidade de Fortaleza - UNIFOR (Mestrado e Doutorado). Líder do Grupo de Pesquisa "Perspectivas principiológicas do Direito e do Processo Penal no Século XXI" (LACRIM - Laboratório de Ciências Criminais - UNIFOR). Advogado criminalista em Fortaleza-CE. E-mail: nestoreasantiago@gmail.com

2 Doutorando pelo Programa de Pós-Graduação em Direito Constitucional da Universidade de Fortaleza. Mestre em Direito Constitucional pela Universidade de Fortaleza. Especialista em Função Social do Direito pela Universidade do Sul de Santa Catarina. Defensor Público do Estado do Ceará. E-mail: eduardoalmendra@yahoo.com.br. 
Resumo: O objetivo do artigo é analisar como os precedentes da Corte Interamericana de Direitos Humanos vinculam os Estados que não tomaram parte de um julgamento, de modo que a decisão seja internalizada pelo ordenamento. Inicialmente se fará uma análise qualitativa do contexto constituinte brasileiro de 1987 para abordar as mudanças interpretativas sobre as normas de recepção dos tratados de direitos humanos e como a recepção da Convenção Americana de Direitos Humanos está atrelada à jurisprudência da Corte Interamericana de Direitos Humanos. Além disso, salienta-se a necessidade de que os Estados participem efetivamente de um diálogo jurisdicional interamericano a fim de fortalecer a democracia por meio dos vínculos substanciais dos direitos humanos na região, numa perspectiva garantista. $O$ método de estudo de casos foi utilizado para conhecer a distinção feita pela Corte Interamericana de Direitos Humanos entre coisa julgada e coisa interpretada e como essa distinção teórica reforça ou não sua jurisdição. Foram utilizadas decisões da Suprema Corte Nacional de Justiça do México e do Supremo Tribunal Federal brasileiro no que pertine à eficácia vinculante e erga omnes.

Palavras-Chave: Corte Interamericana de Direitos Humanos. Precedente. Constituição. Efeito vinculante. Garantismo.

Abstract: The main goal of this paper is to analyze how the precedents of the Inter-American Court of Human Rights are binding on States that have not taken part in a trial, so that the decision is internalized by the legal system. Initially, we conduct a qualitative analysis of the Brazilian constitutional framework of 1987, to address the interpretative changes on standards of reception of the human rights treaties, and how the reception of the American Convention on Human Rights is linked to the case law of the Interamerican Court of Human rights. It also emphasizes the need for the States to effectively participate in an inter-American court dialogue, in order to strengthen democracy, through the substantial ties of human rights in the region, within a guaranteeist perspective. The case study method will be used to determine the distinction made by the Inter-American Court of Human Rights, between res judicata and res interpretata, and how this theoretical distinction reinforces its jurisdiction or oth- 
erwise. For this purpose, the decisions of the Supreme National Court of Justice of Mexico and of the Supreme Court of Brazil are used, in relation to binding and erga omnes effectiveness.

Keywords: Inter-American Court of Human Right. Precedent. Constitution. Binding effect. Guaranteeism.

Resumen: El objetivo de este artículo es analizar cómo los precedentes de la Corte Interamericana de Derechos Humanos vinculan los Estados que no tomaron parte de un juzgamiento, de modo que la decisión sea internalizada por el ordenamiento. Inicialmente se hará un análisis cualitativo del contexto constituyente brasileño de 1987 para abordar los cambios interpretativos sobre las normas de recepción de los tratados de derechos humanos y cómo la recepción de la Convención Americana de Derechos Humanos está ligada a la jurisprudencia de la Corte Interamericana de Derechos Humanos. Además, se resalta la necesidad de que los Estados participen efectivamente en un diálogo jurisdiccional interamericano a fin de fortalecer la democracia por medio de los vínculos sustanciales de los derechos humanos en la región, en una perspectiva garantista. El método de estudio de casos fue utilizado para conocer la distinción que hace la Corte Interamericana de Derechos Humanos entre cosa juzgada y cosa interpretada, y cómo esa distinción teórica refuerza o no su jurisdicción. Se utilizaron decisiones de la Suprema Corte Nacional de Justicia de México y del Supremo Tribunal Federal brasileño en lo que se refiere a la eficacia vinculante y erga omnes.

Palabras Clave: Corte Interamericana de Derechos Humanos. Precedente. Constitución. Efecto vinculante. Garantismo.

\section{INTRODUÇÃO}

República Federativa do Brasil internalizou a Convenção Americana
de Direitos Humanos (CADH) através do Decreto n. 678, de 06 de
novembro de 1992, cujo objetivo foi a incorporação de mais um vínculo material - tendo em vista a existência dos direitos fundamentais já 
previstos pela Constituição da República Federativa do Brasil (CRFB ou CF) - tanto para a produção de decisões políticas e judiciais quanto para a criação de normas jurídicas, isto é, a validade das normas produzidas pelos poderes Executivo, Legislativo e Judiciário teriam que se submeter a um duplo teste de parametricidade, ou seja, devem ser compatíveis tanto com a CRFB quanto com a $\mathrm{CADH}$, sob pena de inconstitucionalidade no primeiro caso e inconvencionalidade no segundo.

A vinculação do ordenamento jurídico pátrio aos direitos humanos tornou-se mais estreita na medida em que o Decreto 4.463, de 08 de novembro de 2002, impôs como obrigatória a competência jurisdicional da Corte Interamericana de Direitos Humanos (CorteIDH) na interpretação e na aplicação da CADH.

Contudo, não se propõe o estudo de como será a implementação das decisões da CorteIDH que eventualmente venham a condenar a República Federativa do Brasil, assunto de elevada importância. Buscar-se-á estudar como os precedentes daquele órgão jurisdicional são tratados, ou seja, se há um diálogo jurisdicional na utilização desses precedentes e com que eficácia são tratados, além de traçar o fundamento de incorporação desses precedentes, haja vista a recepção da CADH e da jurisdição da CorteIDH pelo ordenamento jurídico pátrio, não se olvidando a existência de linha de comunicação constitucional prevista no $\$ 2^{\circ}$ do art. $5^{\circ}$ como dos princípios fundamentais da CRFB e do fortalecimento do Estado Democrático de Direito.

A importância do estudo está na incompatibilidade de entendimento entre a CorteIDH e o Poder Judiciário brasileiro sobre a interpretação de direitos humanos, como a existência de prescrição nos crimes contra a humanidade, o direito à liberdade de expressão em face de servidor público em contraste com a ameaça do crime de desacato. Daí porque a importância da pesquisa em adequar a recepção do Decreto n. 4.463/02 dentro da hierarquia normativa pátria, dentro do bloco de constitucionalidade, funcionando o diálogojurisdicional entre a CorteIDH e o Supremo Tribunal Federal (STF) como instrumento de preservação de direitos essenciais à pessoa humana para poder posicionar-se dentro do sistema democrático do poder.

Não se olvide que o tolhimento de direitos humanos-fundamentais interfere na atividade volitiva de uma pessoa, pois essa é encoberta por uma névoa que 
não lhe permite enxergar, já que não terá liberdade dentro de um ambiente igual para participar da tomada de decisão. Logo, o processo democrático sem substância padece de sabor, torna-se como um bolo de festa em que há requinte e beleza na decoração, mas com massa insípida e com recheio azedo; portanto a proeminência que a CRFB dá aos direitos humanos-fundamentais, arregimentando para a sua proteção a participação da CorteIDH e do Poder Judiciário, tem a função de permanente construção do Estado Democrático de Direito em que se funda a República Federativa do Brasil.

\section{INCORPORAÇÃO DA CADH PELA REPÚBLICA FEDERATIVA DO BRASIL: DEBATES CONSTITUINTES E MUDANÇA INTERPRETATIVA APÓS A PROMULGAÇÃO}

A CRFB trouxe uma mudança de perspectiva necessária para o contexto que o país viveu após o golpe de 1964, quando uma coalizão civil-militar depôs o presidente eleito em exercício. Há necessidade de fazer um recorte histórico sobre esse período, uma vez que se abordarão apenas os fatos históricos que antecedem a promulgação da CRFB, especialmente as discussões que envolveram a necessidade de uma nova Constituição e a tramitação desse texto no Congresso Constituinte de 1987.

\section{EMENDA CONSTITUCIONAL DE 26/85 E A ESPERANÇA DE} MUDANÇA

Em 27 de novembro de 1985 foi promulgada Emenda 26 à Constituição de 1967/69, cujo objeto foi a convocação para que os membros do Congresso Nacional se reunissem a partir de 01 de fevereiro de 1987 como Assembleia Nacional Constituinte (art.1, cabeça da Emenda Constitucional n. 26/87) para que elaborassem, discutissem e promulgassem uma nova Constituição.

O surgimento dessa convocação não decorreu de um passe de mágica, ou mesmo exclusivamente da necessária virtù que os detentores do poder devem ter, mas da conjunção da constante pressão que se fazia de baixo para que 
houvesse a criação de fato de um ambiente democrático de garantia e prática de direitos humanos e da visão de esgotamento do regime. Para Carvalhoª a resposta à pergunta: "Por que teriam o General Geisel e seus aliados tomado a iniciativa de começar a desmontar o sistema autoritário?" pode ser encontrada, resumidamente, em 3 fatores: a) o regime, para alguns dos seus idealizadores, deveria ter tempo certo e não perdurar indefinidamente; b) o país estava no início da década de 1970 vivendo o milagre econômico, que tinha termo final, e que poderia demonstrar que o tal milagre "beneficiou de maneira muito desigual os vários setores da população. A consequência foi que, ao final, as desigualdades tinham crescido ao invés de diminuir ${ }^{4 \prime}$; c) outro fator teria sido o desvio de função de vários servidores, pois a atração à vida política teria criado uma ambição desmedida nessas pessoas, bem como o surgimento de grupos que usavam a tortura com meio de repressão e obtenção de informações, as vezes de forma independente e com ameaça à hierarquia, levando os militares a serem vistos como torturadores ${ }^{5}$.

Dentro do ambiente de surgimento democrático destaca-se o movimento pelas eleições diretas para Presidente da República, que, apesar da sua derrota, levou a uma mobilização popular que até aquele momento não possuía registro na história do País ${ }^{6}$; mas mesmo a derrota da Emenda não ruiu o caminho que se trilhava para a abertura do Estado em que a sociedade estava se movendo. Portanto não se pode afastar a noção de que a redemocratização da década de 1980 trouxe uma nova visão sobre a cidadania, pois se iniciou a construção de um conceito que açambarcaria classes que antes não estavam encobertas pelo direito a ter direitos, reconhecendo-se assim que até aquele momento a expressão da cidadania ocorria apenas em um contexto somente formal de participação política e não material, que corresponde ao dever de proteção da pessoa, mesmo que essa não tenha participado politicamente ${ }^{7}$.

3 CARVALHO, José Murilo de. Cidadania no Brasil: o longo caminho. 14. ed. Rio de Janeiro: Civilização Brasileira, 2011, p.173.

4 CARVALHO, José Murilo de. Cidadania no Brasil: o longo caminho, p. 168.

5 CARVALHO, José Murilo de. Cidadania no Brasil: o longo caminho, p.174 e 175.

6 CARVALHO, José Murilo de. Cidadania no Brasil: o longo caminho, p. 188.

7 MARTINS, Eduardo Almendra. Democracia e acesso à justiça: Defensoria Pública como instrumento de acesso aos direitos e garantias fundamentais. Dissertação (Mestrado em Direito Constitucional). Universidade de Fortaleza. Fortaleza, 2012, p 45. 
Mas mesmo com essas dificuldades não se pode olvidarque o "pluripartidarismo posterior e limitado, admitido para as eleições de estaduais e para o Congresso Nacional em 1982, trouxe novos atores políticos". Logo, esses atores são responsáveis por uma guinada na inserção de alguns avanços no texto, devendose destacar a possibilidade de apresentação de propostas populares ao texto da constituição que então se discutia, abertura que propiciou uma maior participação popular direta por meio de algumas associações de classe ${ }^{8}$, bem como as constantes audiências públicas que se realizam no Congresso Constituinte no seio das subcomissões temáticas, cujo objetivo era aprofundar as discussões sobre os temas entregues a cada uma dessas.

Mesmo que tímida, essa abertura dentro do processo constituinte foi ao encontro das aspirações de construção de um novo cenário político-jurídico que propiciasse o acesso igualitário das liberdades públicas, uma vez que até aquele momento se vivia com o rompimento da liberdade de pensamento, vedação a associações, falta de acesso universal de qualidade à saúde, à educação e ao alimento ${ }^{9}$. Nesse cenário de adequação da ordem interna a um ambiente de proteção à liberdade e à igualdade é que surge a preocupação constituinte em vincular, através da Constituição em gestação, os poderes constituídos, pois a legitimidade tanto da obra constituinte quando do exercício futuro daqueles poderes dependeriam da congruência com a perspectiva social de proteção aos direitos e às garantias individuais, em que cada um pudesse ter igualdade no usufruto dos serviços prestados pelo Estado para ter condições de efetivo gozo de escolhas de projetos de vida. Daí porque a legitimidade do poder, da 8 LOPES, Júlio Aurélio Vianna. A carta da democracia: o processo constituinte da ordem pública de 1988, p. 38.

9 "Parece razoável afirmar que o processo constituinte de 1987/1988 rompeu com o paradigma recorrentes ao longo das outras assembleias constituintes, senão para 'refazer as instituições desde os seus fundamentos', pelo menos para proporcionar-lhes um salto de qualidade. Na verdade, a chave para o entendimento do processo constituinte formal de 1987/1988 começa pela participação popular, pela ativação da sociedade, na revolta silenciosa contra o caráter excludente, desmobilizador, do autoritarismo burocrático (...) no Brasil de 1987/1988, o poder constituinte pode ser entendido, em boa medida, como a tentativa de, novamente, organizar a fantasia, isto é, buscar o término da construção nacional, por meio de um plano de transformações sociais e do Estado, fundada na visão de um projeto nacional de desenvolvimento e na perspectiva de que a crise constituinte brasileira se superaria com o cumprimento do projeto constitucional de 1988". (MORAES FILHO, José Filomeno de. Constituição econômica brasileira: história e política. Curitiba: Juruá, 2011, p. 137-138). 
soberania, se dá na medida em que esse atende à necessidade e à finalidade de sua existência, principalmente através de uma obediência voluntária ${ }^{10}$.

Nesse sentido, Fleiner-Gerster afirma que "enquanto possibilidade de exercer uma influência, o poder depende, antes de tudo, da força de persuasão, da confiança, bem como da disposição do indivíduo de ser convencido ${ }^{11 " . ~ H e l l e r ~ a f i r m a ~ q u e ~ a ~}$ estabilidade estatal se atribui muito mais ao sacrifício espontâneo de cada indivíduo na sua condição pessoa e patrimonial, do que propriamente na coação ${ }^{12}$.

Logo, não passou despercebido pelo Constituinte de 1987 a necessidade de o Estado legitimar seu poder pela preservação da pessoa por meio de direitos fundamentais, de forma a incutir no povo confiança nas normas cridas pelo Estado. Exemplo desta preocupação está contido na existência de um espaço de não fossilização de direitos e garantias fundamentais, que, apesar de não estarem expressos no texto constitucional, possuem estrutura de norma materialmente constitucional e servem para oxigenar a CRFB. ${ }^{13}$

Portanto se observa que o intuito constituinte foi o de abrir a porta constitucional aos tratados internacionais de direitos humanos, concedendo a esses um nível hierárquico idêntico aos das normas de direito e garantias fundamentais previstas na CRFB, ou seja, o $\$ 2^{\circ}$ do art. $5^{\circ}$ funcionária como receptor de normas de direitos e garantias internacionais decorrentes de tratados internacionais, possibilitando o aumento desses direitos e garantias no plano interno, ficando a cargo dos poderes constituídos o processamento constitucional de recepção do tratado.

10 BONAVIDES, Paulo. Ciência Política. 19. ed. São Paulo: Malheiros Editores, 2012, p. 129.

11 FLEINER-GerSTER, Thomas. Teoria Geral do Estado. São Paulo: Martins Fontes, 2006, p. 244.

12 HELLER, Hermann. Teoria do Estado. São Paulo: Editora Mestre Jou, 1968, p.261.

13 Seria de todo indicado, para concluir, recordando uma vez mais a compatibilização entre esses tratados e o Direito Interno, que a nova Constituição explicitasse, dentre os princípios que regem a conduta do Brasil no plano nacional e internacional, a promoção e a proteção dos direitos humanos, entendidos estes como abrangendo tanto os consagrados na própria Constituição, ou os decorrentes do regime democrático, que ela estabelece, quanto os consagrados nos tratados humanitários de que o Brasil é parte e nas declarações internacionais sobre a matéria de que o Brasil é signatário. TRINDADE, Antônio Augusto Cançado. Apresentação. Audiência pública sobre direitos e garantias individuais no plano internacional. Assembleia Nacional Constituinte: atas de comissões. $11^{\circ}$ reunião realizada e a 5 a reunião de Audiência Pública, em 29 de abril de 1987, da Subcomissão dos direitos e garantias individuais. Comissão da soberania e dos direitos e garantias do homem e da mulher, p. 95. Disponível em: <http://www.senado.gov.br/publicacoes/anais/constituinte>. Acesso em: 09 de abril de 2014. 
Contudo, o que se viu foi uma mudança interpretativa relativamente ao $\S 2^{\circ}$ do art. $5^{\circ}$ da CFRB, pois o STF não incorporou a finalidade da alteração constitucional, permanecendo durante largo período com a interpretação pré-constitucional, ou seja, segundo Maués ${ }^{14}$, com a inserção daquele dispositivo pelo Constituinte de 1987 criou-se uma expectativa que o STF passaria por uma mudança de entendimento, na medida em que havia um de dava tratamento constitucional aos tratados de direitos humanos em que o país fosse parte. Todavia, na ADI n. 1.347, o STF não quis utilizar-se um tratado internacional para invalidar uma norma, logo não reconheceu aquele como parâmetro pertencente ao bloco de constitucionalidade pátrio. Mesmo diante dessa frustração inicial, os intérpretes não oficiais da constituição não se quedaram inerte e continuaram a insistir no desacerto do STF e na necessidade de revirement (mudança) dos precedentes que liam a CRFB com o olhar centrado na Constituição anterior.

\section{EMENDA CONSTITUCIONAL N. 45: HIERARQUIZAÇÃO DE TRADADOS SOBRE DIREITOS HUMANOS?}

Desde a previsão de um receptor de normas de direitos humanos na CRFB, e após a manutenção da jurisprudência do STF que desconsiderou essa abertura e manteve os tratados de direitos humanos ao nível da legislação ordinária, que a doutrina constitucional argumenta a necessidade de mudança nesse entendimento.

Piovesan ${ }^{15}$ é uma dessas intérpretes que buscam demonstrar que o $\S 2^{\circ}$ do art. $5^{\circ}$ é instrumento suficiente a receber os tratados de direitos humanos em nível constitucional, ou pelo menos materialmente constitucional: ela sublinha que os direitos humanos incorporados por tratados possuem tanto a hierarquia de normas constitucionais, como aplicabilidade e eficácia imediata na ordem jurídica interna, vinculando todos os poderes para que suas prescrições se tornem operativas.

14 MAUÉS, Antonio Moreira. Supralegalidade dos tratados internacionais de direitos humanos e interpretação constitucional. In: D'ÁVILA LOPES, Ana Maria; MAUÉS, Antonio Moreira (Orgs). A eficácia nacional e internacional dos direitos humanos. Rio de Janeiro: Lumen Juris, 2013. p. 29-30.

15 PIOVESAN, Flávia. Temas de direitos humanos. 7. ed. São Paulo: Saraiva, 2014, p. 62 
Mesmo que até o momento não tenha havido a aceitação institucional da ideia de normatividade simétrica entre tratado de direitos humanos e norma constitucional - aqui se frise materialmente constitucional - é de destacar-se a mudança de entendimento do STF na recepção daqueles tratados com nível de supralegalidade.

Contudo, dentre os que defendem a normatividade materialmente constitucional dos tratados de Diretos Humanos, ainda se poderia questionar qual teria sido a mudança de perspectiva para esses autores sobre a introdução do $\$ 3^{\circ}$ no art. $5^{\circ}$ da CRFB pela Emenda Constitucional n. 45/2004: se haveria uma hierarquia entre normas constitucionais dentro da CRFB, para os que defendem a normatividade constitucional dos tratados de Direitos Humanos, bem como se a eficácia dos tratados de Direitos Humanos frente o reconhecimento do seu nível supralegal diante das normas constitucionais.

\section{ADEQUAÇÃO RECEPTIVA DOS TRATADOS SOBRE DIREITOS}

HUMANOS

Como já foi dito anteriormente, acredita-se que a CRFB foi elaborada para que os tratados de direitos humanos fossem recepcionados como normas constitucionais. Primeiro, porque o art. $1^{\circ}$, III que traz para o texto jurídico constitucional a dignidade da pessoa humana, "impõe-se como núcleo básico e informador do ordenamento jurídico brasileiro, como critério e parâmetro de valoração a orientar a interpretação e compreensão do sistema constitucional instaurado em 1988 ${ }^{16 " ;}$ logo a dignidade da pessoa humana leva a uma abertura moral que visa proteger a pessoa na sua identidade ôntica, ou seja, não faz dessa um fim para algo, não relativiza a condição do ser humano, mas o singulariza, ou seja, "a pessoa humana passou a ser vista como portadora de uma dignidade inata. Por isso que titular do 'inalienável' direito de se assumir tal como é: um microcosmos. Devendo-se-lhe assegurar todas as condições de busca da felicidade terrena ${ }^{17 "}$.

16 PIOVESAN, Flávia. Temas de direitos humanos, p.61

17 BRITTO, Carlos Ayres. O humanismo como categoria constitucional. Belo Horizonte: Editora Fórum, 2010, p. 20. 
Segundo, a prevalência dos direitos humanos internacionais vincula todos os poderes, como esclareceu o Min. Celso de Mello na decisão do HC 87.585 ${ }^{18}$, não se devendo fazer uma interpretação restritiva do alcance desses princípios apenas para as relações internacionais, pois do contrário se teria uma contradição na medida em que o país adotaria todo o respeito aos direitos humanos, mas no âmbito interno estaria livre para violá-los ${ }^{19}$. Nesse sentido manifesta-se Mazzuoli20 ao afirmar que tanto a dignidade da pessoa humana e a prevalência dos direitos humanos são princípios constitucionais que vão ao encontro de um paradigma humanista e protetivo contido também no âmbito internacional, salientado que a CF trouxe uma base axiológica por meio de princípios jurídicos, cuja função é balizar as interpretações que se faz do ordenamento jurídico ${ }^{21}$.

Dentre esses vínculos apontados anteriormente não se pode olvidar a importância de um terceiro, que é a cidadania, que deve ser vista como o arcabouço normativo que envolve a pessoa dentro de um Estado com os direitos e garantias que este elege como meios aptos a propiciar a dignidade social a ser atingida dentro do escopo dos objetivos enumerados no art. $3^{\circ} \mathrm{da} \mathrm{CF}^{22}$. Por tudo isso é que se pode afirmar que a previsão do $\$ 2^{\circ}$ do art. $5^{\circ}$ da CRFB confere aos direitos humanos recepcionados pelo país como normas constitucionais ${ }^{23}$.

18 Nessa decisão em que se discutiu o nível hierárquico dos tratados de Direitos Humanos recepcionados fora da dicção dentro da dicção do $\S 2^{a}$ do art. $5^{\circ}$ da CRFB/88, logo após a EC n. 45/04 que inseriu o $\S 3^{\circ}$ naquele art. 50, o Min. Celso de Mello assim se manifestou: "[Tenho] para mim que uma abordagem hermenêutica fundada em premissas axiológicas - constitucionalmente consagrado (art. 40, II) - da 'prevalência dos direitos humanos' permitirá, a esta Suprema Corte, rever a sua posição jurisprudencial quanto ao relevantíssimo papel, à influência e à eficácia (derrogatória e inibitória) das convenções internacionais sobre direitos humanos no plano doméstico e infraconstitucional do ordenamento positivo do Estado Brasileiro". (Disponível em: <http://www.stf.jus.br/portal/jurisprudencia/ listarJurisprudencia.asp?s1=\%28HC\%24\%2ESCLA $\% 2 \mathrm{E}+\mathrm{E}+87585 \% 2 \mathrm{ENUME} \% 2 \mathrm{E} \% 29+\mathrm{OU}+\%$ 28HC\%2EACMS\%2E+ADJ2+87585\%2EACMS\%2E\%29\&base=baseAcordaos\&url=http:// tinyurl.com/ah2udpa>. Acesso em: 04 de junho de 2015).

19 PIOVESAN, Flávia. Temas de direitos humanos, p. 69.

20 MAZZUOLI, Valerio de Oliveira. O controle jurisdicional da convencionalidade das leis. São Paulo: Editora Revista dos Tribunais, 2009, p. 21

21 MAZZUOLI, Valerio de Oliveira. O controle jurisdicional da convencionalidade das leis, p. 21.

22 Não se está a discutir nesse texto se os estrangeiros dentro do território brasileiro possuem ou não direitos fundamentais, mas se sublinha que o texto fala de pessoas e não em nacionais.

23 PIOVESAN, Flávia. Temas de direitos humanos, p. 62 
Mazzuoli24 vai no mesmo caminho e afirma que o $\S 2^{\circ}$ do art. $5^{\circ}$ da CRFB reconhece: (a) expressamente os tratados de Direitos Humanos como fonte normativa constitucional de proteção dos direitos e das garantias das pessoas; e (b) uma eficácia irradiante de princípios expressos e implícitos no texto constitucional, bem como decorrentes do Estado Democrático de Direito, da República e da Democracia contidos naquele texto, afirmando o autor que naquela previsão está contemplada uma "dupla fonte normativa".

Contudo o cenário da recepção dos tratados de Direitos Humanos sofreu um revés, pois além do receptor de normas de direitos humanos previstos no $\$ 2^{\circ}$ do art. $5^{\circ}$ da CRFB, houve a inserção de mais um parágrafo no mesmo art. 50; diante desse cenário surgiu uma dúvida sobre a teoria da recepção como normas constitucionais dos tratados de Direitos Humanos.

Piovesan ${ }^{25}$ critica inicialmente $0 \$ 3^{\circ}$ do art. $5^{\circ}$ do $C R F B / 88$, pois sua redação deveria ter sido de uma verdadeira interpretação autêntica do Poder Constituído no sentido de esclarecer que todos os tratados já recepcionados pelo $\$ 2^{\circ}$ daquele art. $5^{\circ}$ o foram como normas constitucionais. Todavia, preferiu-se criar uma aparência de hierarquização entre tratados de direitos humanos, colocando aqueles existentes antes da Emenda Constituicional n. 45/2004 em nível inferior à $\mathrm{CRFB} / 88$ e os tratados recepcionados posteriormente a ela como constitucionais, desde que obedecessem ao quorum das propostas de emendas à CRFB (art. 60, $\left.\$ 2^{\circ}\right)^{26}$. Para efeitos de compatibilização, Piovesan afirma que o quorum especial buscou apenas sublinhar o nível constitucional dos tratados de direitos humanos, concedendo-Ihes um nível formalmente constitucional, não alterando o quadro até então vigente, qual seja, que os tratados incorporados de acordo com o $\$ 2^{\circ}$ do art. $5^{\circ}$ são material e formalmente constitucionais.

Esse entendimento decorre de quatro argumentos: a) a interpretação sistemática da Constituição, de forma a dialogar os $\S \S 2^{\circ} e 3^{\circ}$ do art. $5^{\circ}$, já que oúltimo não revogou o primeiro, mas deve, ao revés, serinterpretado

24 MAZZUOLI, Valerio de Oliveira. O controle jurisdicional da convencionalidade das leis, p. 23

25 PIOVESAN, Flávia. Temas de direitos humanos, p. 65.

26 Ainda não se faz a discussão sobre o nível supralegal dos tratados de direitos humanos, pois até aqui se está a trabalhar com a premissa de que esses são normas constitucionais, independentemente da recente decisão do STF. 
à luz do sistema constitucional; b) a lógica e racionalidade que devem orientar a hermenêutica dos direitos humanos; c) a necessidade de evitar interpretações que apostem em agudos anacronismos da ordem jurídica; e d) a teoria geral da recepção do Direito brasileiro ${ }^{27}$.

A posição de Piovesan dá uma solução racional e razoável aos tratados recepcionados nos termos do $\$ 2^{\circ}$, anteriormente ao $\$ 3^{\circ}$, mantendo-se uma harmonia interna no texto constitucional. Contudo, haveria uma dúvida a ser sanada de qual seria a posição dos tratados de direitos humanos que não fossem recepcionados pelo quorum qualificado de $2 / 3$, uma vez que não há no $\$ 3^{\circ}$ do art. $5^{\circ}$ a obrigatoriedade de que todos os tratados de direitos humanos sejam recepcionados com quorum qualificado.

Mazzuoli ${ }^{28}$ inicialmente critica o receptor de normas de direitos humanos do $\S 3^{\circ}$ do art. $5^{\circ}$ da CRFB por ser incongruente, uma vez que aparentemente cria uma hierarquia entre tratados de direitos humanos, bem como dá ao Congresso Nacional o poder de decidir discricionariamente, sem claros parâmetros para o controle de qual tratado será recepcionado nos termos do $\$ 3^{\circ}$ do art. $5^{\circ}$ da CRFB e qual não será, pois essa discricionariedade instalaria uma arbitrariedade legislativa, uma vez que violaria a "completude material do bloco de constitucionalidade"29, isto é, não obrigaria o legislador a incorporar todos os tratados sobre direitos humanos da mesma forma, de modo a possibilitar uma hierarquização entre eles.

Em segundo lugar, deve-se deixar expresso que, mesmo diante das incongruências daquele $\$ 3^{\circ}$, é dever do intérprete compatibilizar seus efeitos futuros com o do $\$ 2^{\circ}$, uma vez que não houve revogação deste, nem podem existir palavras inúteis em qualquer texto jurídico, principalmente no texto constitucional; portanto, com o $\S 3^{\circ}$ não há que se falar em hierarquia externa entre tratados de direitos humanos nem mesmo em uma hierarquia interna no texto constitucional. Mazzuoli ${ }^{30}$ afasta essas duas interpretações e argumenta que a distinção se faz

27 PIOVESAN, Flávia. Temas de direitos humanos, p. 66.

28 MAZZUOLI, Valerio de Oliveira. O controle jurisdicional da convencionalidade das leis, p. 30-31.

29 MAZZUOLI, Valerio de Oliveira. O controle jurisdicional da convencionalidade das leis, p. 31.

30 MAZZUOLI, Valerio de Oliveira. O controle jurisdicional da convencionalidade das leis, p. 44. 
apenas no plano formal de recepção dos tratados de direitos humanos dentro da CRFB. O argumento de Mazzuoli baseia-se na afirmação de que no §2 está previsto um receptor de normas de direitos humanos que confere "status de norma constitucional" àqueles incorporados sem um quorum qualificado, diferentemente do que ocorre no $\$ 3^{\circ}$, em que há uma norma que atribui aos direitos humanos que passam por aquele quorum uma "equivalência a emendas constitucionais". Logo, o "status" garante aos direitos humanos a sua integração ao bloco de constitucionalidade material, uma vez que essa incorporação é menos ampla da que se atribui ao tratado quando ele é incorporado como "equivalente" a uma emenda constitucional, sendo, portanto, material e formalmente constitucional.

Essa interpretação feita por Mazzuoli torna compatíveis os efeitos do $\S 2^{\circ}$ e $\S 3^{\circ}$ do art. $5^{\circ} \mathrm{daCRFB}$, mantendo-os harmonicamente paralelos como receptores normativos de direitos humanos previstos no texto constitucional ${ }^{31}$, pois "os novos tratados de direitos humanos a serem ratificados, por força do $\$ 2$ do mesmo art. $5^{\circ}$, independentemente do quorum de aprovação, serão normas materialmente constitucionais ${ }^{32 "}$.

A discussão anterior não perdeu sua pertinência em virtude da decisão a respeito da recepção das normas de direitos humanos terem sido temporariamente resolvida pelo Supremo Tribunal Federal, já que em decisão conjunta do habeas corpus (HC) n. 87.585/TO e do HC n. 92.566/SP, ambos de relatoria do Min. Marco Aurélio; do Recurso Extraordinário (RE) n. 466343, de relatoria do Min. Cezar Peluso; e RE n. 349.703, tendo como relator o Min. Carlos Britto, decidiu-se acatar a tese do Min. Gilmar Mendes a respeito da recepção dos tratados de direitos humanos como normas supralegais.

Com essa decisão se estabilizou, temporariamente, a discussão sobre qual o status normativo da $\mathrm{CADH}$, que ingressou no sistema jurídico brasileiro por

31 Não se pode olvidar que entre Mazzuoli e Piovesan há uma divergência, que não desestrutura a harmonia geral do pensamento de ambos, quanto à leitura retroativa do $\S 3^{\circ}$ sobre o $\S 2^{\circ}$. Para Piovesan, como já afirmado no texto, o $\S 3^{\circ}$ não infirmaria a recepção formal e material feita pelo $\S 2^{\circ}$ até o início de vigência daquela RNDH. Contudo, para Mazzuoli, apesar de não ser expresso, o $\S 3^{\circ}$ faria uma releitura retroativa interpretativa sobre o RNDH do $\S 2^{\circ}$ para nele ver uma recepção apenas material, mas que poderia tornar-se formal se passe pelo quorum qualificado do $\S 3^{\circ}$ (MAZZUOLI, Valerio de Oliveira. O controle jurisdicional da convencionalidade das leis, p. 45). Essa divergência interpretativa não prejudica a teoria de que o RNDH do $\$ 2^{\circ}$ prevê uma abertura residual, materialmente normativa para os tratados de direitos humanos após o ingresso do RNDH do $\S 3^{\circ}$, ambos do art. $5^{\circ}$ da CRFB. 
meio do Decreto n. 678, de 06 de novembro de 1992, ficando o Brasil obrigado a cumprir integralmente seu texto, como se depreende do art. $1^{\circ}$ do decreto ${ }^{33}$.

\section{DIREITO E NORMA PRODUZIDA JUDICIALMENTE}

O direito é produto da cultura humana e dela recebe sua influência para a mudança. Essa adaptabilidade do direito não era vista como um fenômeno ligado ao Poder Judiciário, tanto que Montesquieu defendia que a função judiciária não era expressiva na divisão dos poderes, bem como sua função se deveria limitar a expor o que a lei dizia: "[Dos] três poderes aos quais nos referimos, o judiciário é de alguma maneira, nulo. (...). Mas os juízes da nação são como dissemos, apenas a boca que pronuncia as palavras da lei, seres inanimados que não podem moderar em sua força, nem seu rigor. ${ }^{34 "}$. Contudo, não se deve transportar criticamente a afirmação de Montesquieu para hoje sem a contextualização necessária, pois aquela inspiração limitativa do Judiciário está dentro do contexto do liberalismo clássico, cuja finalidade era trazer segurança jurídica através da lei, produto da representação da razão humana e da vontade cambiante de detentores do poder.

Hoje a função jurisdicional não é mais vista como antes, pois aquela ideia de que o direito é produção da vontade humana e que deve se manter atualizado para acompanhar os avanços da sociedade aderiu ao seu ser. Logo, a visão unifocal da lei como única expressão do direito fica à margem da contemporaneidade, e se passa a ter uma linguagem bifocal do direito - ainda ligado à criação institucional do Estado - como representado tanto na lei quanto na decisão jurisdicional. Portanto, quando se diz que o direito é norma jurídica, deve-se compreender tanto a função legislativa como a jurisdicional como participantes de peso igual na construção e na adaptação destas normas jurídicas, pois "sendo o direito nada mais que um instituto cultural de claras raízes históricas, ou seja, não é uma construção natural, pode sofrer alterações pelo decurso do tempo e de acordo 33 Art. $1^{\circ}$. A Convenção Americana sobre Direitos Humanos (Pacto de São José da Costa Rica), celebrada em São José da Costa Rica, em 22 de novembro de 1969, apensa por cópia ao presente decreto, deverá ser cumprida tão inteiramente como nela se contém.

34 MONTESQUIEU, Charles-Louis de Secondat. Do espírito das leis. Tradução, introdução e notas de Edson Bini. Série Clássicos. São Paulo: Edipro, 2004, p. 193, p. 195. 
com as compreensões vigentes no tempo e no espaço ${ }^{35 " .}$

Não se afasta mais da função jurisdicional sua característica como fonte formal do direito, de construtor de sentido de determinados textos normativos que são intencionalmente produzidos assim pelo legislador para que tenham perenidade temporal, ficando a cargo do Judiciário a extração da norma vinculante, não cabendo mais na atual quadra histórica divergências amparadas em sistemas jurídicos, como o da separação rígida entre common law e civil law, pois em ambos os precedentes judiciais há a mesma função como fontes formais do direito, gozando, assim, da mesma autoridade $^{36}$. Há, portanto, um diálogo contínuo de busca de soluções a problemas comuns entres esses sistemas ${ }^{37}$. Daí não ser possível manter a divergência entre os grandes sistemas com base na diferença de atribuição de valor à funçãojurisdicional, uma vez que ambos identificam nela uma fonte formal do direito. A mudança de paradigma, ou talvez a aceitação do poder de criador da jurisdição na interpretação jurídica, pode ser atribuída, dentre outros fatores, ao que Nunes ${ }^{38}$ chama de "processualismo constitucional democrático", enfatizando que a criação da norma jurídica não se dá de forma unilateral, mas é precedida de uma diálogo (em contraditório) de sujeitos na busca de influenciar em uma decisão, essa portanto que não é solipsista, mas advém de um processo marcadamente "comparticipativo e policêntrico", cuja estrutura se volta para a criação da norma jurídica do caso concreto, pois não de se pode olvidar que "[A] norma somente adquire o seu significado conforme a individualização pelo interprete no momento da aplicação. Por essa razão, a doutrina fala em normas como resultado e não o pressuposto da atividade interpretativa ${ }^{39 "}$.

A decisão do caso concreto pode e deve ser utilizada em casos semelhantes, pois a confiabilidade nas decisões está na universalidade delas para os mesmos casos, sendo essa característica, para Tucci, "o componente axiológico que sempre revestiu 35 MARTINS, Eduardo Almendra. Democracia e Acesso à justiça: Defensoria Pública como instrumento de acesso aos direitos e garantias fundamentais, p. 2.

36 TUCCI, José Rogério Cruz e. Precedente judicial como fonte do direito. São Paulo: Revista dos Tribunais, 2004, p. 23.

37 BUSTAMANTE, Thomas da Rosa. Teoria do precedente judicial: a justificação e a aplicação de regras jurisprudenciais. São Paulo: Editora Noeses, 2012, p. 13.

38 NUNES, Dierle. Processualismo Constitucional Democrático e o dimensionamento de técnicas para a litigiosidade repetitiva: a litigância de interesse público e as tendências "não compreendidas" de padronização decisória. Revista de Processo, São Paulo, n. 199, p. 49.

39 ZANETI JR., Hermes. O valor vinculante dos precedentes: o modelo garantista (mg) e a redução da discricionariedade judicial. Uma teoria dos precedentes normativos formalmente vinculantes. Salvador: Editora Juspodivm, 2015, p. 142. 
a ideia de Justiça 'como qualidade formal'40". Logo, a interpretação judicial deve esforçar-se para ser a mais bem construída de forma que sua linguagem, partindo do texto normativo, possa produzir normas universais e imparciais; do contrário, não se terá um precedente judicial padrão para casos futuros - em que as condições de aplicação sejam as mesmas - pois não haveria regra universal a ser extraída ${ }^{41}$.

\section{GARANTISMO: A VINCULAÇÃO AOS DIREITOS HUMANOS NA INTERPRETAÇÃO JUDICIAL}

Ficou claro anteriormente que a norma produzida judicialmente é feita dentro de um processo constitucional democraticamente previsto, portanto se pode dizer que há regras procedimentais e substanciais que servem como parâmetros da produção e da correção dessas normas.

Tais parâmetros estão previstos na CRFB, quando essa entroniza direitos e garantias fundamentais como vinculantes às esferas de decisão institucional dentro do Estado, ou seja, a decisão produzida por esse não pode violar nenhum direito previsto dentro da esfera do não decidível e deve contemplar aqueles direitos que impõem àquele decidir: no primeiro caso, se está dentro das liberdades; no segundo, se está dentro dos direitos sociais.

Daí porque se pode afirmar que a hermenêutica possui uma função importante na construção e na consolidação de um Estado Democrático de Direito ancorado em direitos fundamentais, cujas liberdades civis devem ser distribuídas em igualdade de condições. Afirma Ferrajoli que os direitos fundamentais quando "estabelecidos em constituições rígidas, operam como limites e vínculos à produção normativa de nível subordinado42". Isto é, a produção de normas jurídicas não pode atender apenas ao processo de produção formal, já que este se refere apenas ao âmbito de validade procedimental. Logo, para que haja a completude de sua formação, faz-se mister sua adequação conteudística.

40 TUCCI, José Rogério Cruz e. Precedente judicial como fonte do direito, p. 25.

41 BUSTAMANTE, Thomas da Rosa. Teoria do precedente judicial: a justificação e a aplicação de regras jurisprudenciais, p. 114

42 FERRAJOLI, Luigi. Por uma teoria dos direitos e dos bens fundamentais. Tradução Alexandre Salim, Alfredo Copetti Neto, Daniela Cadermatori, Hermes Zaneti Junior, Sergio Cadermatori. Porto Alegre: Livraria do Advogado, 2011, p. 109. 
Segundo Rosa ${ }^{43}$, o proceder do Poder Judiciário é de um ator jurídico-político que atenta para a validade substancial das normas e não somente sobre sua forma (vigência), paradigma trazido pelo garantismo: "para que una norma sea válida además de vigente (...) es también necessário que sus contenidos sustanciales respeten los princípios y los derechos fundamentales estabelecidos em la Constitución ${ }^{44 "}$.

Desta forma, o juiz não pode ser "um burocrata informado pelo arsenal técnico disponibilizado pela dogmática jurídica, valorizador da forma, em desfavor da substância ${ }^{45 "}$. O garantismo abre uma porta para que o intérprete se coloque como agente de consciência da realidade que o circunda, dotando o texto de maior significado. Nessa mudança de perspectiva, Rosa cita a importância da virada linguística, "segundo a qual a linguagem deixa de ser vista como mero instrumento de transmissão do real, para ser seu co-constituinte ${ }^{46^{\prime \prime}}$; a linguagem passa a não ser mais apenas como descrição do real, pois o sentido é retirado das influências que o intérprete sofre ao dar-lhe significado pela linguagem, fazendo com que seja marcada pelas práticas sociais do intérprete.

Aqui o preconceito, "entendido como aquele conjunto de valores e crenças arraigados no homem e que dá característica de humanidade ao próprio homem ${ }^{47 ",}$ é o construtor de sentidos do texto por meio da linguagem, vez que o agente interpretativo compartilha da mesma realidade linguística em que o Direito está inserido, logo não é passivo de compreender esse, mas, também, ativo em sua criação ${ }^{48}$. Todavia, não se olvide que a criação do direito deve estar dentro de uma acepção ampla do processo democrático constitucional, dentro de todos os poderes constituídos, pois abrir o espaço público para participação de todos exercerem a tolerância da discordância ${ }^{49}$ é manter a democracia viva na gestão do 43 ROSA, Alexandre de Morais da. O que é o Garantismo Jurídico? Teoria Geral do Direito. Florianópolis: Habitus Editora, 2003, p. 80.

44 FERRAJOLI, Luigi. Derechos y grantías: la ley del maás débil. 7. ed. Madrid: Editoral Trotta, 2010, p. 66.

45 ROSA, Alexandre de Morais da. O que é garantismo jurídico? Teoria Geral do Direito, p. 81.

46 ROSA, Alexandre de Morais da. O que é o garantismo jurídico? Teoria Geral do Direito, p. 91.

47 OMMATI, José Emílio Medauar. A igualdade no paradigma do Estado Democrático de Direito. Porto Alegre: Sergio Antônio Fabris Editor, 2004, p. 37.

48 ROSA, Alexandre de Morais da. O que é garantismo jurídico? Teoria Geral do Direito, p. 93.

49 SEN, Amartya. A ideia de justiça. Tradução Denise Bottmann, Ricardo Doninelli Mendes. São Paulo: Companhia das Letras, 2011, p. 367. 
Estado. Então, verifica-se que a limitação de vozes no debate público está ligada ao enfraquecimento do desenvolvimento humano, pois "[É] difícil escapar da conclusão geral de que o desempenho econômico, a oportunidade social, a voz política e argumentação racional pública estão profundamente relacionados ${ }^{50 "}$.

Portanto, pode-se afirmar que os precedentes, tal como a lei, são produtos de âmbitos de decisão centrados em instituições do Estado que estão vinculados pelo que Ferrajoli chama de paradigma constitucional ou garantista que, segundo ele, "equivale, sob o plano teórico, ao sistema de limites e dos vínculos substanciais, quaisquer que sejam, impostos a todos os poderes públicos por normas de grau superior àquelas produzidas pelo seu exercício ${ }^{51 " .}$

\section{A FORÇA VINCULANTE DOS PRECEDENTES DA CORTEIDH}

Além da $\mathrm{CADH}$ ser fonte normativa já internalizada no país, houve o reconhecimento pelo Decreto 4.463, de 08 de novembro de 2002, art. $1^{\circ}$, caput, da competência jurisdicional da CorteIDH na interpretação e aplicação daquela. Portanto, deveria o Poder Judiciário brasileiro, em todas as instâncias, observar suas decisões no exercício do controle de convencionalidade das normas internas, como já decidiu a CorteIDH nos casos Almonacid Arellano y outros vs. Chile e Trabajadores Cesados del Congresso vs. Peru ${ }^{52}$; pois havendo o mesmo âmbito de aplicação nacional encontrado no regional, não há esquiva para que o precedente judicial da CorteIDH seja utilizado pelo juiz pátrio ${ }^{53}$.

\section{SUPERVISÃO DE CUMPRIMENTO NO CASO GELMAN VS URUGUAI.}

A CADH impõe a todos os países que ratificaram a criação de um ambiente

50 SEN, Amartya. A ideia de justiça, p. 383.

51 FERRAJOLI, Luigi. Garantismo: uma discussão sobre direito e democracia. Tradução de Alexander Araujo de Souza. Rio de Janeiro. Lumen Juris, 2012, p. 27.

52 NOGUEIRA ALCALA, Humberto. Diálogo interjurisdiccional, control de convencionalidad y jurisprudencia del tribunal constitucional en período 2006-2011. Estudios constitucionales, Santiago, v. 10, n. 2, 2012, p. 61 Disponível em <http://www.scielo.cl/ scielo. php?script $=$ sci_arttext\&pid $=S 0718-52002012000200003 \& \mathrm{Ing}=$ pt\&nrm=iso $>$. Acesso em: 31 mar. 2014. http://dx.doi.org/10.4067/S0718-52002012000200003.

53 NOGUEIRA ALCALA, Humberto. Diálogo interjurisdiccional, control de convencionalidad y jurisprudencia del tribunal constitucional en período 2006-2011, p. 70. 
institucional em que haja o respeito aos direitos previstos nela, bem como garantir seu pleno exercício (art.1.154), para tanto é dever daqueles adotar mudanças legislativas ou de outra natureza que permitam o gozo dos direitos e das garantias previstos na CADH (art. $2^{55}$ ), ou seja, o dever de respeitar - que "consiste en cumplir directamente com la norma estabelecida, ya sea absteniéndose de actuar o dando una prestación ${ }^{56 "-}$ bem como garantir os direitos previstos naquela convenção - isto é, o dever de o Estado organizar sua estrutura política de decisão para assegurar o direito às liberdades públicas e os direitos humanos ${ }^{57}$.

Esse dever imposto pela CADH não recai somente sobre os Poderes Legislativo e Executivo; não é essa força normativa que se extrai da convenção, pois como já foi visto, os direitos fundamentais previstos na CRFB são vínculos procedimentais e substanciais aos poderes constituídos. No mesmo sentido estão os direitos humanos previstos na $\mathrm{CADH}$, visto que sua força normativa advém do próprio texto constitucional de 1988.

Diante dessa vinculação é que a CorteIDH declarou inválida uma lei de anistia do Estado uruguaio, sendo que durante a supervisão de cumprimento dessa decisão foi proferida decisão esclarecedora por parte do juiz Mac-Gregor sobre o dever de o Estado diretamente envolvido na demanda respeitar a coisa julgada

54 Artigo 1. Obrigação de respeitar os direitos. 1. Os Estados Partes nesta Convenção comprometem-se a respeitar os direitos e liberdades nela reconhecidos e a garantir seu livre e pleno exercício a toda pessoa que esteja sujeita à sua jurisdição, sem discriminação alguma por motivo de raça, cor, sexo, idioma, religião, opiniões políticas ou de qualquer outra natureza, origem nacional ou social, posição econômica, nascimento ou qualquer outra condição social.

55 Artigo 2. Dever de adotar disposições de direito interno._Se o exercício dos direitos e liberdades mencionados no artigo 1 ainda não estiver garantido por disposições legislativas ou de outra natureza, os Estados Partes comprometem-se a adotar, de acordo com as suas normas constitucionais e com as disposições desta Convenção, as medidas legislativas ou de outra natureza que forem necessárias para tornar efetivos tais direitos e liberdades

56 FERRER MAC-GREGOR, Eduardo, PELAYO MOLLER, Carlos María. LA OBLIGACIÓN DE "RESPETAR" Y "GARANTIZAR" LOS DERECHOS HUMANOS A LA LUZ DE LA JURISPRUDENCIA DE LA CORTE INTERAMERICANA: Análisis del artículo $1^{\circ}$ del pacto de San José como fuente convencional del derecho procesal constitucional mexicano. Estudios constitucionales, Santiago, v. 10, n. 2, 2012, p. 151. Disponível em: <http://www.scielo.cl/scielo. php?script $=$ sci_arttext\&pid $=S 0718-52002012000200004 \& \operatorname{lng}=p t \& n r m=i s o>$. Acesso em: 31 mar. 2014. http://dx.doi.org/10.4067/S0718-52002012000200004.

57 FERRER MAC-GREGOR, Eduardo; PELAYO MOLLER, Carlos María. La obligación de "respetar" y "garantizar" los derechos humanos a la luz de la jurisprudencia de la Corte Interamericana: Análisis del artículo $1^{\circ}$ del pacto de San José como fuente convencional del derecho procesal constitucional mexicano, p. 154. 
internacional, bem como dos Estados não participantes estarem vinculados à coisa jurídica interpretada pela CorteIDH.

A vinculação normativa dos Estados ao respeito da coisa julgada internacional está no art. $67^{58}$ da CADH que determina que suas decisões são definitivas e inapeláveis. Para Mac-Gregor ${ }^{59}$, deste artigo podem ser extraídos dois efeitos da decisão da CorteIDH: a) uma eficácia subjetiva e direta entre as partes; e b) outra objetiva e indireta para os Estados que não foram apertes no processo interamericano.

Mac-Gregor chama o feito objetivo e indireto de "norma convencional interpretada (res interpretata), cujo dever de vinculação se extrai da norma contida no art. 1.1 e art. 2 da CADH em que obriga os países partes a criar condições de respeito e garantia aos direitos humanos previstos naquela convenção".

44. La eficacia interpretativa de la norma convencional debe entenderse como la posibilidad de lograr una efectividad regional estándar mínima de la Convención Americana para ser aplicable por todas las autoridades en el ámbito nacional. Lo anterior se deriva de los artículos 1.1 y 2 del propio Pacto de San José, en virtud de que existe la obligación de los Estados Parte de "respetar" y "garantizar" los derechos y libertades, así como la obligación de "adecuación" -normativa e interpretativapara lograr la efectividad de los derechos y libertades cuando no estén garantizados. Esta última obligación de los Estados Parte es de singular importancia en el Sistema Interamericano de Derechos Humanos y constituye uno de los aspectos fundamentales que lo distingue del Sistema Europeo ${ }^{60}$.

58 Artigo 67. A sentença da Corte será definitiva e inapelável. Em caso de divergência sobre o sentido ou alcance da sentença, a Corte interpretá-la-á, a pedido de qualquer das partes, desde que o pedido seja apresentado dentro de noventa dias a partir da data da notificação da sentença.

59 Apesar da extrema relevância dos efeitos da coisa julgada internacional para o Estado condenado, aqui se abordará especificamente as razões da vinculação existente na vinculação indireta dos Estados não participantes diante do que Mac-Gregor chamou de res interpretata. FERRER MAC-GREGOR, Eduardo. Eficacia de la sentencia interamericana y la cosa juzgada internacional: vinculación directa hacia las partes (res judicata) e indirecta hacia los estados parte de la Convención Americana (res interpretata) (sobre el cumplimiento del caso Gelman vs. Uruguay). Estudios constitucionales, Santiago, v. 11, n. 2, 2013, p. 656. Disponível em<http://www.scielo.cl/scielo.php?script=sci_arttext\&pid=S0718$52002013000200017 \&$ lng $=$ pt\&nrm=iso $>$. Acessos em: 31 mar. 2014. http://dx.doi. org/10.4067/S0718-52002013000200017.

60 FERRER MAC-GREGOR, Eduardo. Eficacia de la sentencia interamericana y la cosa juzgada internacional: vinculación directa hacia las partes (res judicata) e indirecta hacia los estados parte de la Convención Americana (res interpretata) (sobre el cumplimiento del caso gelman vs. Uruguay), p. 662 e 663. 
Mac-Gregor afirma que, desde que a opinião consultiva n. 7/86 da CorteIDH ${ }^{61}$ reconheceu que os artigos 1.1 e 2 são complementares, não podem os Estados esconder-se por trás da falta de legislação interna para tornar efetivo os direitos previstos na $\mathrm{CADH}$, "ya que el sistema mismo de la Convención está dirigido a reconocer derechos y libertades a las personas y no a facultar a los Estados para hacerlo62".

32. La Corte ha resuelto ya que el artículo 14.1 establece el derecho de rectificación o respuesta y que la frase "en las condiciones que establezca la ley" se refiere a diversas condiciones relacionadas con el ejercicio de ese derecho. Por consiguiente, esa frase atañe a la efectividad de ese derecho en el orden interno, mas no a su creación, existencia o exigibilidad internacional. Siendo éste el caso, cabe referirse a las estipulaciones del artículo 2, puesto que tratan sobre el deber de los Estados Partes de "adoptar... las medidas legislativas o de otro carácter que fueren necesarias para hacer efectivos tales derechos y libertades ${ }^{63 \prime}$.

Portanto, o Estado-parte não pode deixar de garantir direitos fundamentais alegando não haver lei interna que o preveja: pelo contrário, deve impor aos outros poderes constituídos que apliquem diretamente a CADH através de sua interpretação. A expressão "ou de outra natureza" não permite olvidar que as normas são produtos de interpretação; logo, as interpretações feitas da CADH pelos juízes são formas de tornar efetivos os direitos ali previstos, enquadrandose nos termos do art. 1.1 dessa convenção ${ }^{64}$.

61 Esta opinião consultiva tratava sobre a aplicação do art. 14 da CADH que trata sobre a garantia de retificar qualquer informação inexata ou ofensiva contra alguém, na falta de lei ou mesmo se essa poderia limitar essa garantia.

62 CORTE INTERAMERICANA DE DIREITOS HUMANOS. Opinión consultiva OC-7/86 del 29 de agosto de 1986. Exigibilidad del derecho de rectificación o respuesta (arts. 14.1, 1.1 Y 2 Convención Americana Sobre Derechos Humanos) solicitada por el Gobierno De Costa Rica. Disponível em: <http://www.CorteIDH.or.cr/docs/opiniones/seriea_07_esp.pdf>. Acesso em: 10 de maio de 2015.

63 CORTE INTERAMERICANA DE DIREITOS HUMANOS. Opinión consultiva OC-7/86 del 29 de agosto de 1986. Exigibilidad del derecho de rectificación o respuesta (arts. 14.1, 1.1 Y 2 Convención Americana Sobre Derechos Humanos) solicitada por el Gobierno De Costa Rica. p. 08.

64 FERRER MAC-GREGOR, Eduardo. Eficacia de la sentencia interamericana y la cosa juzgada internacional: vinculación directa hacia las partes (res judicata) e indirecta hacia los estados parte de la Convención Americana (res interpretata) (sobre el cumplimiento del caso gelman vs. Uruguay), p. 666. 
Sublinhe-se que, quando se diz que todos os poderes constituídos devem aplicar a $\mathrm{CADH}$, não se deve esquecer que as normas extraídas dela vem criadas pela interpretação que a CorteIDH faz através de seus precedentes, que devem ser observados como o mínimo de proteção convencional, não se impedindo que haja um alargamento da proteção aos direitos e garantias humanas e que tal decorra de interpretação contrária à da $\mathrm{CADH}$, se for para ampliar a proteção às pessoas.

54.La eficacia interpretativa de la jurisprudencia interamericana (res interpretata) deriva directamente de la obligación de los Estados Parte de la Convención del respeto, garantía y adecuación (normativa/ interpretativa) a que se refieren los artículos $1^{\circ}$ y $2^{\circ}$ del propio Pacto, teniendo en consideración que conforme a la propia Convención Americana la "Corte [Interamericana] tiene competencia para conocer de cualquier caso relativo a la interpretación y aplicación de las disposiciones de esta Convención que le sea sometido" 84 y "dispondrá que se garantice al lesionado en el goce de su derecho o libertad conculcados" cuando decida que hubo violación de los mismos. 85 Así, la aplicación nacional del estándar interpretativo interamericano asegura el mínimo de efectividad de la norma convencional ${ }^{65}$.

O respeito à coisa interpretada, como mínimo de proteção previsto na $\mathrm{CADH}$, proporciona a concretização em nível nacional da prevalência dos direitos humanos previstos no art. $4^{\circ}$ da CRFB, bem como no objetivo constitucional da criação de uma sociedade livre e justa, despida de quaisquer preconceitos (art. $3^{\circ}$, CRFB): esses princípios vão ao encontro de um direito americano comum na proteção de todos que sofram o mesmo tipo de violação de seus direitos humanos, corolário de uma cidadania universal.

\section{CONTRADICIÓN DE TESIS N. 293/2013}

A Suprema Corte de Justiça da Nação do México (SCJN), após decisão judicial na Contradição de Tese 293/2013, abraçou a vinculação da eficácia da coisa interpretada defendida por Mac-Gregor na supervisão do caso "Gelman vs Uruguai". Naquela decisão, ficou definido que os pontos controversos a serem 65 FERRER MAC-GREGOR, Eduardo. Eficacia de la sentencia interamericana y la cosa juzgada internacional: vinculación directa hacia las partes (res judicata) e indirecta hacia los estados parte de la Convención Americana (res interpretata) (sobre el cumplimiento del caso gelman vs. Uruguay),p. 669. 
enfrentados eram dois: a) o nível hierárquico dos tratados de direitos humanos; b) qual o efeito vinculante da decisão da CorteIDH. Claramente se verifica que o primeiro ponto é preliminar ao segundo, pois esse sofrerá os efeitos decorrentes do entendimento sobre o primeiro.

A SCJN foi acionada para interpretar o artigo $1^{0}{ }^{66}$, da Constituição Política dos Estados Unidos Mexicanos de 1917 (CPEUM) - alterada em junho de 2011, dando nova redação a esse artigo ${ }^{67}$ - que claramente recepciona os direitos humanos previstos nos tratados que o Estado Mexicano tenha ratificado, indo além e deixado expresso que eles serão interpretados conforme seu texto e dos tratados recepcionados da forma mais amplamente protetiva.

Contudo, sublinhe-se que antes da alteração da redação do art. $1^{\circ}$ da CPEUM, a SCJN lia o art. 133, que trata da supremacia constitucional, como subjugando todo e qualquer tratado internacional ratificado pelo México, criando assim uma hierarquia normativa formal do ordenamento jurídico mexicano, cuja localização topográfica dos tratados internacionais era superior às leis internas do país, mas inferior à CPEUM - ou seja, o entendimento era de que os tratados tinham nível supralegal ${ }^{68}$ (CONTRADICCIÓN DE TESIS 293/2011, p. 24)

Novos ares foram trazidos para a CPEUM, tendo a SCJN afirmado que a partir daquela alteração houve um novo marco no parâmetro de validade normativa das normas jurídicas no México, criando-se um bloco de constitucionalidade em sintonia com a máxima proteção aos direitos humanos, ou seja, "la creación de un

66 Artículo 10. En los Estados Unidos Mexicanos todas las personas gozarán de los derechos humanos reconocidos en esta Constitución y en los tratados internacionales de los que el Estado Mexicano sea parte, así como de las garantías para su protección, cuyo ejercicio no podrá restringirse ni suspenderse, salvo en los casos y bajo las condiciones que esta Constitución establece. Las normas relativas a los derechos humanos se interpretarán de conformidad con esta Constitución y con los tratados internacionales de la materia favoreciendo en todo tiempo a las personas la protección más amplia.

67 Essa reforma mexeu significativamente com a proteção dos direitos humanos no Estado Mexicano, como ressalta Carbonell: "Como puede verse, se trata de una reforma que (pese a que es breve en su contenido), abarca distintos temas y aspectos relativos a la concepción y la tutela de los derechos humanos en México" (2012). CARBONELL. Miguel. La reforma constitucional en materia de derechos humanos: principales novedades. Disponível em: <http://www.miguelcarbonell.com/articulos/novedades_printer.shtml>. Acesso em: 07 de junho 2015.

68 MÉXICO. Tribunal Pleno de la Suprema Corte de Justicia de la Nación. Contradicción de tesis 293/2011. Disponível em: <https://www.scjn.gob.mx/Paginas/Inicio.aspx>. Acesso em: 07 de julho de 2014. 
conjunto de normas de derechos humanos, cuya fuente puede ser, indistintamente, la Constitución o un tratado internacional. ${ }^{69 " . ~ N a ~ C o n t r a d i c c i o ́ n ~ d e ~ T e s i s ~ n . ~ 293 / 11 ~}$ resolve-se o ponto da recepção das normas de direitos humanos alçando-as ao nível constitucional, ao reconhecer essa intenção dentro de uma interpretação genética ${ }^{70}$.

A vinculação do Estado do México aos precedentes da CorteIDH, uma vez que a CADH foi incorporada no bloco de constitucionalidade mexicano, foi enfrentada diretamente pela SCJN, que não se esquivou de tratar sobre o assunto. E, imbuída da ideia de construção de um direito comum americano com vistas à proteção de todas as pessoas de forma igual, reconheceu que os precedentes da CorteIDH vinculam todos os poderes constituídos ${ }^{71}$.

Destaca-se da decisão da SCJN a observação de que essa comunga da vinculação da coisa interpretada, bem como destaca que o Estado do México, por ter reconhecido a jurisdição da CorteIDH, assumiu também o compromisso de adotar os precedentes daquela como um mínimo existência por meio de uma interpretação progressista de proteção dos direitos humanos.

69 MÉXICO. Tribunal Pleno de la Suprema Corte de Justicia de la Nación. Contradicción de tesis 293/2011, p. 32

70 En esta línea, de diversos dictámenes de las Comisiones de ambas Cámaras del Congreso de la Unión que participaron en el proceso de reforma, en tanto expresiones de la voluntad del Poder Reformador de la Constitución, se puede apreciar que las modificaciones de seis y diez de junio de dos mil once tuvieron la intención de reconocer el carácter constitucional de todas las normas de derechos humanos, sin importar que su fuente sea la propia Constitución o los tratados internacionales, a efecto de que los operadores jurídicos las utilicen para interpretar el sistema normativo mexicano, erigiéndose así como parámetro de control de regularidad constitucional. (MÉXICO. Tribunal Pleno de la Suprema Corte de Justicia de la Nación. Contradicción de tesis 293/2011, p. 41.)

71 A diferencia de lo anterior, la jurisprudencia interamericana se integra en un sistema de precedentes, 43 según el cual todos los criterios interpretativos contenidos en una resolución dictada por la Corte Interamericana con motivo de un asunto de naturaleza contenciosa gozan de fuerza vinculante, sin necesidad de que se siga un procedimiento formal distinto. En este sentido, cada pronunciamiento del tribunal interamericano se integra a la doctrina jurisprudencial interamericana, cuya fuerza vinculante debe entenderse en clave de progresividad, es decir, como un estándar mínimo que debe ser recibido por los Estados que hayan reconocido la competencia contenciosa de la Corte Interamericana para ser aplicados directamente, en forma armónica con la jurisprudencia nacional, o para ser desarrollados o ampliados mediante jurisprudencia que resulte más favorecedora para las personas. (MÉXICO. Tribunal Pleno de la Suprema Corte de Justicia de la Nación. Contradicción de tesis 293/2011, p. 56). 


\section{POSIÇÃO DO SUPREMO TRIBUNAL FEDERAL}

A CRFB possui um texto em que um dos objetivos foi proteger as pessoas de abusos cometidos pelo Estado. Todavia, vale recordar que a mudança legislativa (aqui constitucional) sem a consequente alteração de costumes sociais e jurídicos de como determinados institutos devem ser lidos gera a vigência sem efeito da norma, pois essa sofre a paralisação eficacial pelos órgãos destinados a sua aplicação, bem como ao desuso ou mesmo à burla de suas finalidades, em detrimento da proteção dos cidadãos. Daí porque tem razão Vianna quando afirma que as mudanças impostas não podem ficar desligadas da tradição do povo, pois do contrário as mudanças pretendidas não terão viabilidade. ${ }^{72^{\prime \prime}}$.

A primeira vista a afirmação de Vianna pode ser contrária ao intuito normativo de respeito e garantia aos direitos humanos; mas não o é, pois como abordado anteriormente, a Constituinte de 1987 não retirou o texto constitucional de um chapéu mágico; ao contrário, aquele Congresso foi a culminação da vontade de mudança e de proteção aos direitos humanos em que vivia o país não só nos antecedentes de sua instalação, mas por todo a quadra histórica brasileira. Exemplo dessa mudança de comportamento social e político ocorreu com o modelo de assistência jurídica no Brasil - por meio de uma instituição, a Defensoria Pública, integralmente preenchida por cargos públicos - para atender pessoas sem condições financeiras, tendo o tempo percorrido até o modelo atual de Defensoria Pública, servido para demonstrar e experimentar outros modelos que não foram bem-sucedidos no acesso aos necessitados ${ }^{73}$.

A defesa e a garantia dos direitos humanos no texto constitucional ficam demonstradas quando se faz um cotejo com a $\mathrm{CADH}$, pois muitos dos direitos previstos nessa estão também previstos naquele; contudo, não se tem tido no Brasil o avanço hermenêutico que ocorre em alguns precedentes da CorteIDH, daí a necessidade de estreitar-se os laços entre esses órgãos jurisdicionais, principalmente

72 VIANNA, Oliveira. Instituições políticas brasileiras. Brasília: Conselho Editoral do Senado, 1999, p 444.

73 ALVES, Cleber Francisco. Justiça para todos! Assistência Jurídica Gratuita nos Estados Unidos, na França e no Brasil. Rio de Janeiro: Lumen Juris, 2006, p. 249. 
após o reconhecimento pelo Decreto 4.463, de 08 de novembro de 2002, art. $1^{\circ}$, caput, da competência jurisdicional dessa. Mas contrariamente a isso, o STF, ao julgar a Ação de Descumprimento de Preceito Fundamental (ADPF) n. 153, olvidando, intencionalmente, os precedentes daquela corte, reconheceu a recepção ultraativa dos efeitos da Lei n. 6.683/79, que anistiou todos os crimes políticos em um determinado lapso temporal. Por meio deste exemplo recente, adverte-se que um texto de natureza convencional, sem ter quem o defenda, não trará mudança alguma, muito menos fazer com que os direitos humanos sejam levados a sério, correndo o claro risco de eles virarem palavras escritas em um nobel humanista.

A força de um texto constitucional não está no lirismo do seu texto, mas na correspondência dele com os "fatores reais do poder" presentes na sociedade que busca regulamentar com durabilidade. Logo não podem existir duas constituições, a real - decorrente das condições históricas e sociais - e a escrita - despida de qualquer ligação com a realidade, sem eficiência alguma, e, caso haja, a segunda sucumbirá à primeira ${ }^{74}$.

Após vários anos, o STF modificou sua jurisprudência sobre o nível legal dos tratados de direitos humanos, passando a tratá-los de forma especial, quando contenham disposições de direitos humanos. Para Maués ${ }^{75}$, aquele tribunal levou em consideração as seguintes razões: a) parâmetro formalmente e material de validade da CRFB/88 sobre os outros diplomas, podendo haver controle de tratados internacionais; b) possibilidade de ampliação do rol de direitos humanos fora da parametricidade interna; c) entendimento de que o $\$ 3^{\circ}$ do art. $5^{\circ}$ da CRFB demonstra a intencionalidade legislativa de manter os tratados anteriores em nível inferior ao do texto constitucional.

As razões aqui apresentadas já foram suficientemente refutadas anteriormente, quando da demonstração de que o STF poderia ter recepcionado os tratados de Direitos Humanos ao nível constitucional. Mas não se nega que a decisão do STF foi um avanço, tanto que para Maués ${ }^{76}$ a supralegalidade possui efeito 74 LASSALE, Ferdinand. A Essência da Constituição. E-book. 8. ed. Rio de Janeiro: Lumen Juris, 2008, p. 33.

75 MAUÉS, Antonio Moreira. Supralegalidade dos tratados internacionais de direitos humanos e interpretação constitucional, p. 32

76 MAUÉS, Antonio Moreira. Supralegalidade dos tratados internacionais de direitos humanos e interpretação constitucional, p.33 
interpretativo semelhante ao do nível constitucional, pois "o STF não apenas interpretou a legislação infraconstitucional de maneira a compatibilizá-la com a CADH, mas também interpretou a própria Constituição com base nesse tratado", já que, para ele, o tratado teria tido o efeito de suspender a eficácia da disposição constitucional que trata sobre prisão civil do depositário infiel, ou seja, a tese da supralegalidade possui o mesmo efeito prático de fazer com que a Constituição seja interpretada de modo a compatibilizar-se com os tratados de direitos humanos recepcionados ${ }^{77}$.

Para sustentar sua argumentação, Maués ${ }^{78}$ informa que o STF tem se utilizado da CADH na preservação e na garantia dos direitos humanos, exemplificando com alguns julgamentos quando isso ocorreu: a) cita o HC n. 99.891 em que o STF, baseado no art. 7.2 da CADH, afirmou não reconhecer na ordem interna a execução provisória da pena; b) no HC n. 85.237, afirmou que a pretensão punitiva do Estado deve conter-se no limite da garantia da duração razoável do processo; b) o art. 8 da CADH teria permitido ao STF a consolidação de vários entendimentos na esfera penal para a preservação da garantia do devido processo, para tanto cita HC n. 88.359 (inépcia da inicial quando não compatível com a CADH), HC n. 93.503 (deve o réu estar presente na audiência de instrução para auxílio da defesa técnica como expressão da autodefesa); e, por fim, c) o RE n. 511.961, em que decidiu não estar recepcionada a necessidade do diploma de curso superior de jornalista, uma vez prevista a liberdade expressão do art. 13 da CADH.

Essas decisões demonstram que o STF está se utilizando da CADH para algumas de suas decisões, mas não se pode negar o fato de que essa interação é muito menor que a utilização de parâmetros externos decorrentes de cortes constitucionais de outros países, como da Suprema Corte dos Estados Unidos da América. Não se afirma que estas não devam ser utilizadas, mas deveriam sê-lo apenas em caso de omissão do diálogo travado com a CorteIDH, ou mesmo para apontar uma inconsistência em um precedente daquela.

77 MAUÉS, Antonio Moreira. Supralegalidade dos tratados internacionais de direitos humanos e interpretação constitucional, p.34

78 MAUÉS, Antonio Moreira. Supralegalidade dos tratados internacionais de direitos humanos e interpretação constitucional, p. 34 e 35 


\section{CONSIDERAÇÕES FINAIS}

A ordem interna possui atualmente dois receptores normativos de direitos humanos que, longe de rebaixarem ou mesmo anularem a influência dos tratados que versem sobre tais direitos, enaltece-os e demonstra como são importantes para a proteção dos cidadãos, pois não se deve esquecer de que o Direito, como expressão de uma cultura, é feito para as pessoas, para que se crie um ambiente harmonioso de convivência com a máxima igualdade e liberdade possível, cujo limite deve ser o princípio geral de viver honestamente e não prejudicar terceiros.

Quando o direito não protege as pessoas, sua finalidade está esvaziada e vira uma peça fria, cuja justificativa passa a ser seus ajustes formais; muito dessa perda de identidade se deve à falta de uma estrutura normativa de proteção e garantia das pessoas, ou o mais grave: a falta de órgãos dispostos a fazê-la efetiva.

Não houve até o presente o reconhecimento correto do nível que se deve dar aos tratados de direitos humanos, mesmo que se tenha demonstrado que essa fora a intenção genética do constituinte. Mas não se pode negar que houve avanços que devem continuar permitindo um maior diálogo entre cortes por meio de seus precedentes, que devem ser lidos como recipientes de normas jurídicas produzidas após a devida interpretação dos textos normativos constitucional e convencional.

Os precedentes como fontes formais que são devem ter espaço na argumentação jurídica, pois são exemplos da conduta dos tribunais e, portanto, detentores de força institucional vinculantes, principalmente para as pessoas que os olham como verdadeiras normas obrigatórias; daí a importante missão do intérprete que não pode se afastar das vinculações formais e materiais dos direitos humanos, pois através desses se poderão criar precedentes seguros e imparciais.

Logo se pode concluir que a CADH não é só uma convenção que traz normas de direitos humanos: ela é um parâmetro americano mínimo de proteção aos direitos humanos. Com essa vocação normativa unitária é que se desenvolvem os precedentes da CorteIDH, cuja função é de subsidiar os Estados-parte na interpretação da $\mathrm{CADH}$, não permitindo que se busquem argumentos que afugentem o mínimo existencial contido nesta convenção. 


\section{REFERÊNCIAS}

ALVES, Cleber Francisco. Justiça para todos! Assistência Jurídica Gratuita nos Estados Unidos, na França e no Brasil. Rio de Janeiro: Lumen Juris, 2006.

BONAVIDES, Paulo. Ciência Política. 19. ed. São Paulo: Malheiros, 2012.

BUSTAMANTE, Thomas da Rosa. Teoria do precedente judicial: a justificação e a aplicação de regras jurisprudenciais. São Paulo: Noeses, 2012.

BRITTO, Carlos Ayres. O humanismo como categoria constitucional. Belo Horizonte: Fórum, 2010.

CARVALHO, José Murilo de. Cidadania no Brasil: o longo caminho. 14. ed. Rio de Janeiro: Civilização Brasileira, 2011.

CARBONELL. Miguel. La reforma constitucional en materia de derechos humanos: principales novedades. Disponível em: <http://www.miguelcarbonell.com/articulos/ novedades_printer.shtml>. Acesso em: 07 de junho 2015.

COELHO, Rodrigo Meirelles Gaspar. Proteção internacional dos direitos humanos: a Corte Interamericana e a implementação de suas sentenças no Brasil. Curituba: Juruá, 2007.

CONVENÇÃO AMERICANA DE DIREITOS HUMANOS. Disponível em: <http://www. ciDireitosHumanos.oas.org/basicos/portugues/c.Convencao_Americana.htm>. Acesso em: 07 de junho de 2015.

CORTE INTERAMERICANA DE DIREITOS HUMANOS. Opinión consultiva OC-7/86 del 29 de agosto de 1986. Exigibilidad del derecho de rectificación o respuesta (arts. 14.1, 1.1 Y 2 Convención Americana Sobre Derechos Humanos) solicitada por el Gobierno De Costa Rica. Disponível em:<http://www.CorteIDH.or.cr/docs/opiniones/seriea_07_esp.pdf>. Acessado em 10 de maio de 2015.

FERRAJOLI, Luigi. Garantismo: uma discussão sobre direito e democracia. Rio de Janeiro. Lumen Juris, 2012.

FERRAJOLI, Luigi. Por uma teoria dos direitos e dos bens fundamentais. Porto Alegre: Livraria do Advogado, 2011.

FERRAJOLI, Luigi. Derechos y grantías: la ley del más débil. 7. ed. Madrid: Editoral Trotta, 2010. 
FERRER MAC-GREGOR, Eduardo. Eficacia de la sentencia interamericana y la cosa juzgada internacional: vinculación directa hacia las partes (res judicata) e indirecta hacia los estados parte de la convención americana (res interpretata) (sobre el cumplimiento del caso Gelman vs. Uruguay). Estudios constitucionales, Santiago, v.11, n.2, 2013, p. 641-694. Disponível em<http://www.scielo.cl/scielo.php?script=sci_arttext\&pid=S0718-5200201300 0200017\&lng=pt\&nrm=iso >. Acesso em: 31 mar. 2014. http://dx.doi.org/10.4067/S071852002013000200017.

FERRER MAC-GREGOR, Eduardo; PELAYO MOLLER, Carlos María. La obligación de "respetar" y "garantizar" los derechos humanos a la luz de la jurisprudencia de la corte interamericana: análisis del artículo $1^{\circ}$ del pacto de San José como fuente convencional del derecho procesal constitucional mexicano. Estudios constitucionales, Santiago, v. 10, n. 2, 2012, p 141-192. Disponível em: <http://www.scielo.cl/scielo.php?script=sci_arttext\&pid=S071852002012000200004\&lng=pt\&nrm=iso > . Acesso em: 31 mar. 2014. http://dx.doi.org/10.4067/ S0718-52002012000200004.

FLEINER-GERSTER, Thomas. Teoria Geral do Estado. São Paulo: Martins Fontes, 2006.

HELLER, Hermann. Teoria do Estado. São Paulo: Mestre Jou, 1968.

LASSALE, Ferdinand. A Essência da Constituição. 8. ed. Rio de Janeiro: Editora Lumen Juris, 2008. E-book.

LOPES, Júlio Aurélio Vianna. A carta da democracia: o processo constituinte da ordem pública de 1988. Rio de Janeiro: TopBooks, 2008.

LOSSURDO, Domenico. Democracia ou Bonapartismo: triunfo e decadência do sufrágio universal. Rio de Janeiro e São Paulo; Editora UFRJ e Editora UNESP, 2004.

MARTINS, Eduardo Almendra. Democracia e Acesso à justiça: Defensoria Pública como instrumento de acesso aos direitos e garantias fundamentais. Dissertação (Mestrado em Direito Constitucional). Universidade de Fortaleza. Fortaleza, 2012.

MAUÉS, Antonio Moreira. Supralegalidade dos tratados internacionais de direitos humanos e interpretação constitucional. In: D'ÁVILA LOPES, Ana Maria e MAUÉS, Antonio Moreira (Org). A eficácia nacional e internacional dos direitos humanos. Rio de Janeiro: Lumen Juris, 2013. p. 27-50

MAZZUOLI, Valério de Oliveira. O controle jurisdicional da convencionalidade das leis. São Paulo: Revista dos Tribunais, 2009. 
MAZZUOLI, Valério de Oliveira; GOMES, Luiz Flávio. Direito supraconstitucional: do absolutismo ao estado constitucional e humanista de direito. São Paulo: Editora Revista dos Tribunais, 2010.

MÉXICO. Constituición Politica de los Estados Unidos Mexicanos de 1917. Disponível em: <http://www.ordenjuridico.gob.mx/Constitucion/cn16.pdf>. Acesso em: 07 de junho de 2015.

MÉXICO. Tribunal Pleno de la Suprema Corte de Justicia de la Nación. Contradicción de tesis 293/2011. Disponível em: <https://www.scjn.gob.mx/Paginas/Inicio.aspx>. Acesso em: 07 de julho de 2014.

MONTESQUIEU, Charles-Louis de Secondat. Do espírito das leis. Tradução, introdução e notas de Edson Bini. Série Clássicos. São Paulo: Edipro, 2004.

MORAES FILHO, José Filomeno de. Constituição econômica brasileira: história e política. Curitiba: Juruá, 2011

NOGUEIRA ALCALA, Humberto. Diálogo interjurisdiccional, control de convencionalidad y jurisprudencia del tribunal constitucional en período 2006-2011. Estudios constitucionales, Santiago, v. 10, n. 2, 2012. p 57-140. Disponível em <http://www.scielo.cl/scielo.php?script=sci_ arttext\&pid=S0718-52002012000200003\&lng=pt\&nrm=iso>. Acesso em: 31 mar. 2014. http://dx.doi.org/10.4067/S0718-52002012000200003.

NUNES, Dierle. Processualismo Constitucional Democrático e o dimensionamento de técnicas para a litigiosidade repetitiva: a litigância de interesse público e as tendências "não compreendidas" de padronização decisória. Revista de Processo, São Paulo, n. 199, set. 2011, p. 41-82.

OMMATI, José Emílio Medauar. A igualdade no paradigma do Estado Democrático de Direito. Porto Alegre: Sergio Antônio Fabris Editor, 2004.

PIOVESAN, Flávia. Temas de direitos humanos. 7. ed. São Paulo: Saraiva, 2014.

ROSA, Alexandre de Morais da. O que é o Garantismo Jurídico? Teoria Geral do Direito. Florianópolis: Habitus Editora, 2003.

SEN, Amartya. A ideia de justiça. São Paulo: Companhia das Letras, 2011.

TELLES JUNIOR, Goffredo. A Constituição, a Assembleia Constituinte e o Congresso Nacional. 2. ed. São Paulo: Saraiva, 2014. 
TRINDADE, Antônio Augusto Cançado. Apresentação. Audiência pública sobre direitos e garantias individuais no plano internacional. Assembleia Nacional Constituinte: atas de comissões. $11^{\circ}$ reunião realizada e a $5^{a}$ reunião de Audiência Pública, em 29 de abril de 1987, da Subcomissão dos direitos e garantias individuais. Comissão da soberania e dos direitos e garantias do homem e da mulher, p. 95. Disponível em: <http://www.senado.gov. br/publicacoes/anais/constituinte>. Acesso em: 09 de abril de 2014.

TUCCI, José Rogério Cruz e. Precedente judicial como fonte do direito. São Paulo: Revista dos Tribunais, 2004.

VIANNA, Oliveira. Instituições políticas brasileiras. Brasília: Editora Conselho Editoral do Senado, 1999.

ZANETI JR., Hermes. O valor vinculante dos precedentes: o modelo garantista (mg) e a redução da discricionariedade judicial. Uma teoria dos precedentes normativos formalmente vinculantes. Salvador: Juspodivm, 2015.

Recebido em: jun/2015

Aprovado em: dez/2015 